\title{
Two Africans and the Elusiveness of Meaning
}

\author{
Jurie Le Roux (University of Pretoria)
}

\begin{abstract}
This article highlights the impossibility of ever grasping fully the meaning of an OT text and how this loss can be approached. Historical criticism underscored the notion that the OT/HB originated over many years: texts were constantly re-interpreted, contexts often changed, older parts were re-adapted and therefore many (even opposing) voices can be heard in the Hebrew Scripture. Notwithstanding difficulties and the elusiveness of meaning, OT scholarship can still be of great value and to elaborate this point the views of two African born scholars are discussed and their "solutions" accentuated. The one suggested that studying the text can be a joyful enterprise and the other African advised that we must always be open to future possibilities.

KEYWORDS: Old Testament/Hebrew Bible, Augustine, Derrida, Monnica, Georgette Safar Derrida, verbum interior, verbum exterior, deconstruction.
\end{abstract}

This article is dedicated to Sakkie Spangenberg, a good friend and an outstanding scholar who often felt the brunt of one-sidedness and fundamentalism, and had to pay a costly price for his critical views on faith and religion. I am grateful to him for what he taught me and for what I have received from him as a colleague and as a friend over many years. I will always cherish it and I wish him all the best for the years to come.

In conjunction with Sakkie's thinking this article emphasises that the elusiveness of meaning will always haunt OT scholars but this is not necessary the end of the road. Below this is illustrated with reference to two African scholars whose views can ease this pain of loss and open up new ways of dealing with texts.

\section{A THE PROBLEM}

Between a word and its understanding, words and their explanation, lies an infinite space. A person can for instance confess God's closeness and love, but to articulate it can be difficult. A person can use the best methods of exposition

* Article submitted: 24/4/2017; peer-reviewed: 3/5/2017; accepted: 28/6/2017. Jurie le Roux, "Two Africans and the Elusiveness of Meaning," Old Testament Essays 30/2 (2017): 367-383, doi: http://dx.doi.org/10.17159/2312-3621/2017/v30n2a11 
and yet the final meaning of the text will always escape him/her. All theology is therefore flawed, incomplete, unfinished and fragmentary. And the reason for that lies in our frailty and fragility as human beings. Our horizon of understanding is always limited by our own historical situation. And this recognition of the "situatedness" of our own understanding, and the limitations it involves, implies an un-dogmatic attitude towards the truth, human beings and the world.

Since the early beginnings of historical criticism in the eighteenth century, OT scholarship has become aware of these limitations. The OT/HB was merely viewed as an expression ("Ausdruck") of a specific era, the manifestation of a life experience ("Erlebnis"), which was embedded in truelife experiences and which we attempt to re-enact ("nacherleben") ${ }^{1}$ or to re-live by means of spiritual empathy. ${ }^{2}$ This observation further emphasised the long development of the OT/HB into its present state, the historically determined nature of its message and the impossibility to reduce it to fixed meanings. ${ }^{3}$

In the light of the above one can indeed pose a question about the relevance of the OT/HB for ordinary people and society. If it has no fixed meaning, why should one spend time on it? In this article this question is being answered with reference to two African scholars who lived centuries apart but who each had his own way of dealing with this question: according to the one, God could be enjoyed despite all problems in the texts, whilst the other emphasised the hope that one day we will understand.

Below their answers are discussed and couched in the form of answers to their mothers whom they loved, respected and cared for. Both mothers were sincerely devoted to their religion but were concerned about their sons' commitment to the faith they were born into. Although both sons took their mothers' religious convictions seriously their answers were different but nevertheless creative and ingenious and even relevant for today.

\section{B THE TWO AFRICANS}

The one African was Augustine and the other Jacques Derrida. Augustine was born in 354 Thagaste on 13 November and died on 28 August 430 in Hippo Regius. His mother was Monnica who lived her Christian faith in a special way and dedicated her life to the conversion of her son. Georgette Safar Derrida was the mother of the other great African, Jacques (or Jackie) Derrida, born in

1 Jean Grondin, “Gadamer’s Basic Understanding of Understanding,” in The Cambridge Companion to Gadamer, ed. Robert J. Dostal (Cambridge: Cambridge University Press, 2002), 36-51.

2 Hermann Gunkel, "The Religio-Historical Interpretation of the New Testament," Monist 13 (1903): 398-455.

3 Konrad Schmid, Is There Theology in the Hebrew Bible? (Winona Lake, IN: Eisenbrauns, 2015), 11-28. 
Algeria on July 15, 1930 and died in $2004 .{ }^{4}$ She was always worried about her son, and often wondered whether he still found comfort in the Jewish faith and visited the synagogue. ${ }^{5}$

Both boys' philosophy and theology, for which they became famous, were (although partly) also an attempt to address the concerns of their mothers about their faith. ${ }^{6}$ Both, however, emphasised one important point: it is not so easy to talk about God, to interpret the Bible and to articulate their faith. Augustine stated that his mother's view of the Trinity could not be explained adequately. A believer can find rest in him but can never expound him. ${ }^{7}$ Derrida did not necessarily reject the Jewish religion or even God but since we have no direct access to events (or religion or God) he would speak differently about his mother's God. ${ }^{8}$

\section{THE TEARS OF A DETERMINED MOTHER}

Monnica cried more about Augustine's lack of faith than a mother crying over the death of a child. Sometimes the pain overwhelmed her to such an extent that she became exhausted. ${ }^{9}$ She found it difficult to discuss matters of faith with her son because he was arrogant, always knew better, and would not be convinced. In addition, she was illiterate and could not verbalise her faith very well, yet she endlessly prayed for his conversion. ${ }^{10}$

In her grief, she could be harsh. When Augustine moved back to Thagasta in 373 she refused staying with him in the same house. The reason was that Augustine joined the Manicheans and was following their "profane heresies.” Monnica was so overcome by grief that she even dreamed of Augustine's conversion. ${ }^{11}$ She consulted others requesting advice how to treat her son. One was a bishop and she insisted him to meet Augustine, wishing that bishop could just talk to the boy and convince him of his heresies, but to no avail. The bishop was agitated and said Augustine must be left alone. If he was so clever as his mother said, he would discover the truth himself. He then said: "Go now because it is impossible for a child which is so clever to be lost."12

Augustine’s crying mother did not let him go. In 383 he became lecturer

4 Catherine Malabou and Jacques Derrida, Counterpath: Travelling with Jacques Derrida (Stanford: Stanford University Press, 2004), 75-89.

5 Simon Glendinning, Derrida (New York: Oxford University Press, 2011), 1-7.

6 John Caputo, The Prayers and Tears of Jacques Derrida (Indianapolis: Indiana University Press, 1997), xvii-xxx.

7 Augustine, Conf. 2.1.

8 Erik Oger, Derrida (Kampen: Klement, 2005), 9-14.

9 Augustine, Conf. 3.11.19-20.

10 Abraham Sizoo, Augustinus (Kampen: Kok, 1957), 82-90.

11 Augustine, Conf. 3.11.20.

12 Augustine, Conf. 3.12.21. 
in rhetoric at Milan and he had to leave Africa. It was a decisive event in his life, and his wailing mother followed him after a while. In Milan she introduced him to Ambrose who was the bishop of Milan, and Augustine became interested in his sermons. ${ }^{13}$ In the year 386 he was converted to his mother's religion and over the years this conversion became famous and was romanticised in many ways. His conversion happened while he was sitting in the garden of his house in Milan and heard the children singing the words "tolle lege" ("take and read"). He then opened the Bible at Rom 13:13-14 and read the following: "Let us behave decently .... as followers of the Lord Jesus Christ."14

On the way back to Africa, Monnica, Augustine and his family waited in Ostia for a ship. There she became ill, died and was buried there. ${ }^{15}$ She was far from Africa and died far from her homeland, but she was happy because her son had been converted to Christianity. Augustine became a believer like his mother but things were complicated. He had to reflect theologically on their common belief but that was not easy. He now had to interpret the Bible and explain God to the members of his church and the task seemed impossible. Between his mother's practical faith and his theological reflection there was a big gap; between his mother's concrete acts of faith and his critical contemplation there was a tension which could never be relieved, because every day he was confronted with at least three challenges, which made easy answers impossible. One was Scripture's meaning that escapes us; another was words that have no fixed meanings and finally God that cannot be understood.

\section{THE MEANING OF THE BIBLE ELUDES US}

When the family of Augustine arrived at the port city of Ostia at the end of 387 waiting for a ship to Africa, Augustine had a vision. ${ }^{16}$ Based on this "vision" it was often wondered whether Augustine was not a mystic using mystical experiences to explain the Bible and understand God. This was, however, not the case. Knowledge of God and the Scripture could not be gained by mystical experiences but only through hard work. In short: “Augustinus verwerpt stavast subjectieve ervaring als middel voor epistemologische vooruitgang voor Godskennis."17

Only persistent study of the Bible can illuminate the text. We can therefore understand the letter he sent to his bishop, Valerius, in 391. He was elected recently yet against his own wishes as presbyter of the church in Hippo

\footnotetext{
13 Augustine, Conf. 5.13.23.

14 Augustine, Conf. 8.12.28-30.

15 Augustine, Conf. 9.11.27-28.

16 Augustine, Conf. 9.10.23-25.

17 Hans Geybels, “Augustinus een mysticus,” in Augustiniana Neerlandica, ed. Paul J. van Geest and Johannes van Oort (Leuven: Peters, 2005), 146.
} 
Regius and needed some time to study the Bible. Many church duties awaited him and soon he would become engaged in a variety of activities such as preaching, home visits, catechism and administration. Augustine knew this and therefore the letter to Valerius. What he requested is interesting: he asked for a short holiday in order to devote all his time and energy to the study of the Bible. It is important to note that prayer and hard work were according to Augustine the basic requirements for researching and understanding of the Bible.

In his great work on Christian doctrine, "De doctrina Christiana," Augustine stated that the reader must always search for the author's intention in the text. That was, however, not an easy task and therefore Augustine took the exegetical rules of Tyconius seriously. ${ }^{18}$ Tyconius was the first

in de latijn sprekende wereld uitgebreid en systematisch zoekt naar de sleutels, passend op het geweldige slot dat Heilige Schrift heet. Hij werd in menig opzicht de vader van de westerse exegese en hermeneutiek. ${ }^{19}$

However, despite all exegetical rules there was always something that escaped the attention of the theologian, something which can never fully be understood or articulated. ${ }^{20}$

Some texts will never be understood and with this we have to come to terms. According to Augustine God deliberately placed difficult passages in Scripture in order to temper the courageous reader. Incomprehensible sections were there to curb the proud, to make the arrogant humble, and to expose the ignorance of the arrogant. No one should have the satisfying feeling of superior intelligence that he/she knows the essential meaning of the entire Bible. Although understanding of the OT requires a lot of hard work and an attitude of humility, the text, however, never opens up its depths. Despite all our endeavours, the final meaning of the text will always elude us and one possible reason for this lies in the nature of words. ${ }^{21}$

\section{E WORDS ARE INCOMPLETE}

Words and their meanings are never fixed. Put differently: words always fall short because they can never say what they ought to say. ${ }^{22}$ Whenever a word is

18 Augustine, Doctr. chr. 3.30-37.

19 Johannes van Oort, Jeruzalem en Babylon (Zoetermeer: Uitgeverij Boekcentrum, 1995), 217.

20 Thijs Rutten, “Augustinus en de spiritualiteit van de Psalmen,” in Augustiniana Neerlandica, ed. Paul J. van Geest and Johannes van Oort (Leuven: Peters, 2005), 111-130.

21 Augustine, Doctr. chr. 1.6-7.

22 Augustine, Doctr. chr. 2.3,6-7. 
uttered, it immediately fades away. According to Augustine we can write down a word in an attempt to save it and to keep it from oblivion but to no avail. ${ }^{23}$ Writing cannot secure the original meaning of words and written texts (like the OT) are signs of something we have lost.

Augustine explained this inadequacy of words beautifully by means of two basic expressions: the "verbum cordis" or "inner word" and the "verbum exterior," the "outer word" or "the uttered word." First of all we consider the "inner word." This is the language of the heart, the words that lie deep within us and are unspeakable; the "verbum cordis" refers to our deepest feelings and speaks a language only we can understand. However, when we express these inner words their true meaning is lost. The spoken word is not capable of conveying the true meaning of the inner word. ${ }^{24}$ No audible or written word can ever convey our deepest feelings and the "language of the heart." 25

This is such an important point that we repeat the essence again. A clear distinction must be made between "verbum cordis" and "verbum exterior." The inner words we cherish inside and the words attempting to articulate these feelings in sound and writing are not identical to the inner word and can never correspond with it. Consequently, no one is ever fully present in the words we speak; the outer word never contains or expresses the full meaning of the "verbum cordis"; there will always remain something of the inner word behind when we utter it: "Was ausgesagt ist, ist nicht alles."26

There is an exception, Augustine says, and that is God. In his Word (Jesus) he fully expressed and "emptied" himself. God's Word became flesh in order for us to understand him. Although God's "verbum exterior" or "outer word" (Jesus) was not the Father, God nevertheless clearly spoke through this Word. Put differently: the Father fully expressed himself in this Word and nothing of God's "verbum cordis" remained behind in his "verbum exterior" Jesus. ${ }^{27}$ Knowledge and love, which resided in God's heart, were voiced fully in the Word. ${ }^{28}$

In the world of human beings, things are totally different. Our words are limited, do not adequately express all our feelings and are therefore unfinished, imperfect, inadequate. There is always something not expressed and everything we say is always something limited, partial and fragmentary. Language always illuminates only one facet of the inner word and the words we say, read or hear

23 Hubertus R. Drobner, Lehrbuch der Patrologie (Freiburg: Herder, 1994), 355-357. 24 Augustine, Trin. 15.11,20 (CCSL 50-50a).

25 Augustine, Trin. 15.10,19 (CCSL 50-50a).

26 Hans-Georg Gadamer, Wahrheit und Methode (Tübingen: JCB Mohr, 1990), 504.

27 Augustine, Trin. 15.13,22 (CCSL 50-50a).

28 Augustine, Trin. 15.14, 23 (CCSL 50-50a). 
are never final. ${ }^{29}$ This is also true of the Bible: the words in the text are the work of humans and do not express the full meaning of the authors and that is why so many things in the Bible remain unclear. Put differently: God is not fully present in the words of the text and these words also do not express the full meaning of those who wrote it. ${ }^{30}$

To summarise: although Bible study implies hard work, its meaning eludes us because the words we read are incapable to fully express the theology of the authors; the words we read cannot fully convey the authors' deepest convictions because words are limited, incomplete and imperfect "instruments" to express the innermost feelings of the authors. And this was also true of Augustine himself: the words he used to preach and to explain the Scriptures were also incomplete and inadequate.

\section{F GOD LIES BEYOND OUR GRASP}

To complicate things there was also something else: the impossibility of ever comprehending God. Augustine was a humble exegete because he had a deep sense of the finiteness of human knowledge. He often stated that others can correct him and invited them to improve on his explanation of the Bible. ${ }^{31}$ The source for this humility can be found in his total inability to fully understand the Trinity and to explain God. And because God is unfathomable and inexplicable nobody's exegesis can be final or absolute.

His incapability to speak about God caused an intellectual as well as a practical dilemma. He often said that we must love God, but how can we love him if we cannot know him intellectually. This problem he could never solve and often despaired. However, Augustine kept on trying but without success. In his "De Trinitate" he more than once intended to explain the Trinity only to admit a few paragraphs later that he cannot. Often he tried, but every time the final words slipped away. At the end of his work on the Trinity he confessed that after several attempts to explain God the Father, the Son and Holy Spirit he was incapable of doing it. He could not say anything meaningful about the Trinity because God remains forever out of our intellectual reach. ${ }^{32}$ And if you cannot fully describe God how can you understand his words in the OT and NT? ${ }^{33}$

Augustine's inability to talk about God thus also influenced his

29 Augustine, Trin. 15.10,11,19,20 (CCSL 50-50a).

30 Gadamer, Wahrheit, 276-291; Jean Grondin, Sources of Hermeneutics (State University of New York: Albany, 1995), 102-104; Jean Grondin, Einführung zu Gadamer (Tübingen: JCB Mohr, 2000), 210-215.

31 Augustine, Trin. 2.9,16 (CCSL 50-50a).

32 Augustine, Trin., 15.27,50 (CCSL 50-50a).

33 Jean Grondin, Einführung in die Philosophische Hermeneutik (Darmstadt: Wissenschaftliche Buchgesellschaft, 2001), 50-59. 
exegesis. He could never explain the psalter in depth, never fully formulate its message and never verbalise its theology in clear and final terms because God always eluded his intellectual grasp. His many vain attempts to understand God emphasised his inability to ever understand the Bible fully.

\section{G THE WAY OUT: LOVE AND ENJOYMENT}

Augustine showed us a way how to deal with this "incompleteness" of our understanding of the Bible/ OT, the postponement of meaning and the inability to exegete texts in absolute terms. According to Augustine "love" can help us to overcome this abyss because without love all exegetical work are in vain. Each text says something about the love for God and the neighbour. When this two-sided love for God and the neighbour cannot be found in a text it is a sign that we must start all over again. Augustine expressed it clearly: without love the study of Scripture has absolutely no significance. Or as he formulated it:

So anyone who thinks that he has understood the divine Scriptures or any part of them, but cannot by his understanding build upon this double love of God and neighbour, has not yet succeeded in understanding them. ${ }^{34}$

Even though our exegesis may seem imperfect and limited, yet if it is immersed in love for God and our neighbour, it is better than a cold, loveless interpretation of Scripture. Every text therefore has only one theme: love for God and the neighbour. This is what we must search for in every text and if we cannot highlight that, all our exegetical endeavours are without value.

We can also explain this with reference to the distinction between "use" and "enjoy." 35 To enjoy something is to focus our full attention on it and to appropriate it. To use something is to use it for some or other purpose. Augustine applied it to God and the Bible: the only "object" that we must enjoy in life and onto whom we should hold fast, is God; in order to experience this joy and happiness the Bible is essential; it is the instrument by which we can enjoy God; by using the Bible God's presence is felt and his love (for God and humankind) discovered. ${ }^{36}$ Of all things we can enjoy on earth nothing surpasses the happiness, which we can experience in the Father, the Son and the Holy Spirit:

These three have the same eternal nature, the same unchangeableness, the same majesty, the same power. In the Father there is unity, in the Son equality, and the Holy Spirit a harmony of unity and equality. And the three are all one because of the Father, all equal

34 Augustine, Doctr. chr. 1.36,40-41.

35 Van Oort, Jeruzalem, 119-122.

36 Augustine, Doctr. chr. 1.35,36,39,40. 
because of the Son, and all in harmony because of the Holy Spirit. ${ }^{37}$

A mere scientific study of the Bible without love was thus impossible for Augustine and although we do not fully understand Scripture we can nevertheless enjoy God through the Bible. ${ }^{38}$

At the beginning of August 386 Augustine was converted to the faith of his mother in Milan and she was overwhelmed by joy and tears because this was the fulfilment of all her prayers over many years. Monnica died a year later in Ostia and Augustine had to continue and develop her (and also his) faith tradition further. Put differently: he had to give content to their common faith by means of critical reflection but soon discovered that it was no easy task. His mother's beliefs were probably naïve, down-to-earth and more childlike while those of her son were more critical and analytical, and he also recognised the many problems attached to their faith. The more he reflected on God the more he discovered that God lies beyond our reach and can not be described. Consequently the meaning of the Bible/OT can also never fully be grasped and therefore he suggested a way out by focusing on love and enjoyment. Although not all is clear in the Bible/OT we must nonetheless concentrate on the traces of God's love and the love for the neighbour in a given text. There was also something else: enjoy God by means of the Bible. In short: he could have told his mother that faith in God and understanding of the Bible/OT are much more complicated than expected, but despite our no-understanding we can still enjoy God and search for his love in Scripture. ${ }^{39}$

This was Augustine's answer to the problem of not knowing but Jacques Derrida dealt with the matter in a completely different way. He also had a mother to whom he had to answer about God and faith.

\section{H A JEWISH MOTHER'S CONCERN}

Georgette Safar Derrida often wondered whether her son, Jackie, still visited the synagogue, adhered to the Jewish faith and found meaning in the Jewish traditions. She was reluctant to approach him directly and asked others about his faith ${ }^{40}$ Like Monnica she also travailed in pain each time she saw her "son going away from Him." ${ }^{41}$ She had reason to be concerned because Jackie married outside the Jewish faith, his sons were never circumcised, and according to many he was an atheist who severed all ties with the "covenant people.” Derrida loved his mother and at the time of her illness and eventual

37 Augustine, Doctr. chr. 1.4,4.

38 Augustine, Doctr. chr. 1.6-7.

39 Gerald Bonner, "Augustine as Biblical Scholar," in The Cambridge History of the Bible, ed. Peter R. Ackroyd and C. F. Evans (Cambridge: Cambridge University Press, 1989), 541-563.

40 Caputo, Prayers and Tears, xvii.

41 Augustine, Conf. 9.9.22. 
death in Nice he remained next to her bed. In pursuit of his "compatriot" Augustine he wrote a kind of Jewish "Confessiones" which he called "Circumfession." 42 The connections between Derrida and Augustine are indeed remarkable: Augustine lived in Numidia, contemporary Algeria which was also Derrida's birthplace; Derrida lived in a street called Rue Saint Augustin, and his "Circumfession" was a kind of dialogue with Augustine whose mother died in Ostia. ${ }^{43}$

Derrida, however, never severed his ties with the Jewish faith. This for instace can be seen in his words about his "tallith," his prayer robe that he received as a child. ${ }^{44}$ Derrida's intense commitment to this piece of garment informs us about his commitment to the Jewish faith. So attached was he to this shawl that he "never, ever, considered it to throw it away." He never wanted to wear it, but almost every night he stroked it with his fingers or kissed it with his lips. He did not always know why he was so attached to it or to whom he had entrusted his life at that moment but he could not stop doing it. ${ }^{45}$ And the fact that he lived with a physical mark, a Jewish mark, the physical mark of circumcision on his body, prevented him from simply breaking the link with the "covenant people." 46

Georgette Derrida's son Jackie thus thought constantly about God, but in different ways. He could not leave God, but he could not talk about him in absolute terms or language. He had his own language in which he spoke to God and he thought about God in his own way. ${ }^{47}$ He remained attached to the Torah but his interpretation of the text was different and his way of reading was called "deconstruction." 48

\section{A TRAGIC LOSS OF REALITY}

How could Derrida have explained his views about God and religion to his mother? A good starting point could have been the tragic experience of loss. He could have described to her the feeling of loss that is underlying our human

42 Jacques Derrida, "Composing 'Circumfession,"” in Augustine and Postmodernism: Confessions and Circumfession, ed. John D. Caputo and Michael J. Scanlon (Bloomington: Indiana University Press, 2005), Kindle ed., Part 1, ch 1.

43 Jacques Derrida, “Circumfession,” in Jacques Derrida, ed. Geoffrey Bennington and Jacques Derrida (Chicago: University of Chicago Press, 1993), 1-23.

44 John D. Caputo, "Shedding Tears Beyond Being," in Augustine and Postmodernism: Confessions and Circumfession (Bloomington: Indiana University Press, 2005), Kindle ed., Part II, ch. 5.

45 Derrida, "Composing," Part I, ch. 1.

46 Caputo, Prayers and Tears, 255-262.

47 Jacques Derrida, “Geloof en wete: Die twee bronne van die 'religie' op die grense van die suiwere rede,” trans. Johann Rossouw, Frag 2 (1998): 14-38.

48 Egide Berns, “Jacques Derrida en de taalfilosofie,” in Denken in Parijs, ed. Egide Berns, Samuel Ijsseling, and Paul Moyaer (Brussel: Samson, 1979), 166-169. 
condition and consequently our incapability to fathom the mysteries of life, the words in the Torah and God's existence. He could also have explained it in terms of our inability to grasp the uniqueness and inability to repeat events. Put differently: we are not able to grasp the meaning of things and events that occur in our daily lives.

We can describe this by referring to historical events, which elude us and refuse exact description. Historical moments in our own lives and in the history of the world are inaccessible. We do not posses it and we cannot reach out to it because it is gone. This is due to the nature of a historical event: it denies us access; it keeps us at bay; it always escapes meaning. When we reach out to grasp the event it is already too late. When we "appear" the event has already "left." Put differently: we are latecomers - when we "arrive" it is already too late because the event has already "gone." When we investigate Israel's past, for instance, the true nature of the events can never be determined. We have lost something (the quintessence of those events) and no (historical) method or (historical) document can retrieve it. It can also be explained by the terms "quod" (the "that") and the "quid" (the "what") of the event. History writing focuses on the questions pertaining to the "quod" while the "quid" (or the meaning of the event) remains inaccessible. ${ }^{49}$

To explain this "singularity of the event" we can say that every event (in our lives or in Israel's history) has a certain individuality, which is characteristic of just that event. Every event has its own uniqueness, which is always lying beyond reason's grasp. Every event has a certain particularity, which will forever remain out of our reach. Every time when reason (or science) attempts to appropriate this "quid" of the event, everything is lost. Everything turns into ashes, so to speak. And so severe is the loss that we can mourn and weep over it forever. It is a loss that can never be reversed and therefore there is the overwhelming sense of mourning. Because the loss is absolute, the mourning is absolute. Nothing can be done about it:

Ons kan net huil oor die onvervangbare verlies en (ons) eie onmag ten opsigte daarvan, oor die (vuur-) as wat die singuliere as getuie van haar vlugtige aanwesigheid agtergelaat het. ${ }^{50}$

And language cannot help us either. All words are always wounded words: ${ }^{51}$ wounded because they speak in general terms about reality (and the past) and are therefore not able to depict the uniqueness of things and events; wounded because they cannot express the essential meaning of life or the world and, as Augustine would have said: words cannot adequately articulate the

49 Daniël Goosen, "Verlies, rou en affirmasie: Dekonstruksie en die gebeure," Frag 1 (1998): 55-60.

50 Goosen, "Verlies," 70.

51 Jacques Derrida, Of Grammatology (Baltimore: Johns Hopkins), 1976, $27-73$. 
"verbum cordis" or the innermost feelings of the heart. Words, however, also hurt reality. They harm because they always distort reality, making a caricature of it and do violence to the uniqueness of life and the world. What a wellknown Derrida scholar said of Meister Eckhart is perhaps also true of Derrida: he

is a salient example of this recognition that language is caught up in a self-defeating enterprise ... that language keeps on saying what it says, undoing what it does, and in general failing again and again to make good on its claims. ${ }^{52}$

Not even texts with dates can succeed in seizing, keeping, holding the "quid," the essence or meaning of any event or things that happened in our lives. According to Derrida, dates indeed mark singularity or the once-in-alifetime experience, and he referred to the poet Paul Celan who used dates in his poems..$^{53}$ It was an attempt by Celan to remember the uniqueness of an event but neither the date nor the words in the poem could retain the uniqueness of an event. Everything was lost the moment it was written down and dated. A date tells us that this or that happened in this place and in this specific moment, and a date in the poem "wants to keep the trace of this irreplaceable uniqueness" but it fails to keep the event in its fullness. A date wants "to preserve the uniqueness of the moment but what, by the same token, loses it." The tragedy of the human condition lies in the experience of the loss of reality; in words that are wounded because they are incapable of expressing uniqueness and dates that lose what they want to keep and burn what they want to save. ${ }^{54}$

Derrida's intense experience of loss made it impossible for him to speak like his mother in a "traditional" way about God, the Hebrew Scripture and the Jewish faith. He followed different intellectual routes and in the end he was confronted with this experience of loss and his inability to speak in conventional or orthodox terms about religion.

\section{J DAILY PRAYERS}

Derrida could nevertheless have consoled his mother with the fact that he prayed each day and that his "tallith" meant much to him. He could have told her that "I could rightly pass for an atheist" but that he still prayed. ${ }^{55} \mathrm{He}$ has been praying all his life and "his experience of prayer is the secret source of everything." He also stated, "that if those reading me" can only see "my tears" and only realise that "I lived in prayer, tears." That was the reason for his attachment to his prayer shawl, which "I like to touch more than to see, to

52 John Caputo, "Mysticism and Transgression: Derrida and Meister Eckhart," in Derrida and Deconstruction, ed. Hugh J. Silverman (London: Routledge, 1989), 29.

53 Jacques Derrida, Points ... (Stanford: University Press, 1995), 375.

54 Derrida, Points, 378.

55 Derrida, “Circumfession,” 155. 
caress every day, kiss without even opening my eyes.”56

However, there was a problem: "he was at a loss to where his prayers arise, if they rise at all, or where they drift, if they adrift, like letters lost in the mail.” Derrida did not know the destination of his prayers and if it was God, he was not capable of describing, depicting him. Like Augustine he would ask, "What do I love when I love you,"57 but Derrida's answer differed from that of Augustine. The latter still wanted to enjoy and praise the "unknown” God but for Derrida things were more difficult. He did not know who this God was and he confronted us with the radical consequences of exactly that. Tears and a feeling of loss will always accompany all talking about God because we suffer from an inability to understand God and to speak in absolute terms about him. Augustine also said something similar but nevertheless wanted to enjoy God and praise him. According to Derrida that was just too easy and once again followed a different route. He found hope in what came to known as "deconstruction."

\section{K A GLIMMER OF HOPE}

We thus have no firm grip on texts, meaning, God, et cetera. Whatever we study, there will always remain something we do not completely understand and which reason cannot explain fully. ${ }^{58}$ However, the notion of deconstruction can offer some hope. It is a difficult concept and as Derrida explained to a Japanese friend, "deconstruction is everything and nothing at the same time." Deconstruction is an event, "a happening thing." Often deconstruction is viewed as an attempt to destroy faith and all forms of truth; to undermine religion and theology and introducing an intellectually violent era in which no certainties prevail and anything goes. This destructive view, however, was never the intention of Derrida and his notion of deconstruction. The latter merely wants to accentuate our vulnerability and emphasise that meaning (of say a text) is always a kind of delayed meaning. It is never just there in all its fullness but something that we must wait upon. Meaning (of say a text) is not immediately available but something that will one day and one moment dawn upon us unexpectedly. Theology implies extremely hard work but also an attitude of waiting; waiting for an unexpected moment of insight, understanding, comprehension that will just overcome us. ${ }^{59}$

Deconstruction is therefore an act of hope. Hope for the impossible to happen. Hope that perhaps one day we will grasp something more profoundly than yesterday or the day before. This may seem impossible but Derrida urged us never to give up hoping and yearning for an understanding, which is deeper

56 Caputo, “Shedding Tears," Part II, ch.5.

57 Augustine, Conf. 10, 6-7.

58 Derrida, “Geloof," 14-38.

59 Derrida, “Composing,” Part I, ch. 2. 
and profounder than the popular explanations of the masses. ${ }^{60}$

Put differently: Derrida challenges us to at least dream and think about the possibility of different or other ways of understanding. Deconstruction is a longing for something tout autre, a desire for the other (possibilities of understanding) to enter our lives and overthrow the existing boundaries: "the incoming of the other, the coming of something we did not see coming, that takes us by surprise and tears up our horizon of expectation.” And deconstruction remains open to the newcomer (or new meanings), which is invited to become part of us and our horizon of understanding. Deconstruction shows respect to this newcomer and even opens up spaces where the new can happen, the unique can be experienced and the singularity can be comprehended. ${ }^{61}$

Those who think differently will not be content with fixed truths, easy answers, quick solutions to difficult exegetical problems and popular theological formulations satisfying the superficial taste of the masses. ${ }^{62}$ Deconstruction, therefore, implies resistance against mediocrity:

Die kritieklose aanvaarding van kleinburgerlike denke, die tevredenheid met die bestaande orde, die aanvaarding van woorde se vaste betekenisse asook teologiese of politieke denksisteme wat die volle waarheid wil omsluit. Dekonstruksie wil mense teen die maklike oplossings van die lewe, die oorvereenvoudige verklaring van tekste, die probleemlose spreke oor God, die onbuigsame interpretasies van die verlede, die vasvang van die lewe in eenduidigheid waarsku en selfs beskerm. ${ }^{63}$

To resist this easy answers Derrida emphasised the importance of the "Aufklärung” (Enlightenment) which must always inspire us never to forego reason and always nurture the "the desire for critique and truth."64

Derrida loved his mother therefore he stayed alongside her sickbed writing his "Circumfession" and waiting for the moment of death. He often wondered when and how death would come and while waiting, he also pondered about God and faith and Jewishness and how he differed from his mother. At least he could tell her that he also prayed every day but that God lies outside of our grasp. However, there is always the hope that in future we

60 Caputo, John D. and Michael J Scanlon, "Introduction: Apology for the Impossible: Religion and Postmodern,” in God, Gift, and Postmodernism, ed. John D. Caputo and Michael J. Scanlon (Bloomington: Indiana University Press), 1999.

61 Jacques Derrida, Limited Inc. (Evanston, IL: Northwestern University Press, 1997), 8-9.

62 Oger, Derrida, 164-165.

63 Jurie H. le Roux, “Twee Afrika ma’s en hulle seuns,” in Afdrukke, ed. Dirk J. Human and Daniël P. Veldsman (Pretoria: UP, 2011), 100.

64 Caputo, Prayers and Tears, 90. 
will understand God, the world and humankind differently and perhaps more profoundly than in the past.

\section{A LAST THOUGHT}

To be an OT scholar implies a confrontation with our limitations as well as that of OT scholarship. We (as human beings) have lost something and no historical method can retrieve it. As we have said at the beginning of the article, this is not necessarily the end of the road and the two Africans convincingly illustrated that. There is enough in die OT to enjoy or to hope for; abundant perspectives which can be appropriated despite problems concerning words, texts and contexts.

This view also has consequences for theology as well as OT study in particular. Theology must never be a search for the true, eternal, final meaning

maar (moet) veel eerder die kultivering van 'n veelvoud van betekenismoontlikhede (wees), en die verlustiging in 'n verskeidenheid van stemme, verhale en geskiedenisse van 'n wêreld wat weliswaar minder vas en seker voorkom, maar daarom juis ook ligter, meer oop, meer buigsaam en, in 'n uitgesproke sekulêre sin, meer moontlik. ${ }^{65}$

Each day we experience reality

in 'n eindelose hoeveelheid van betekenismoontlikhede, verskeidenheid van geskiedenisse en asimmetriese tekens wat by ons die besef laat van voortdurende differensie, uitstel en meersinnigheid. ${ }^{66}$

Old Testament scholarship must start every day at point zero accepting the critical OT scholarship of the past two centuries as well as the notion that the final meaning will always escape us and that our words are incapable of conveying our deepest theological intentions. And in our scholarly engagement with the text there are at least two possibilities open: like Augustine we can enjoy God through the Scripture despite historical critical results, or like Derrida wait and hope that meaning will one day come over us and change our lives.

\section{BIBLIOGRAPHY}

Augustine, Aurelius. Confessiones. Delft: WD Meinema, sino anno. . De trinitate. CCSL 50-50A. Turnhout: Brepols Typographi Editores Pontificii, 1968. ."De doctrina Christiana." Pages 1-293 in Augustine: De Doctrina

Chrisitana. Edited by Robert P. H. Green. Oxford: Clarendon Press, 1995.

65 Marinus Schoeman, “Kritiek en die krisis van representasie,” Frag 1 (1998): 102. 
Berns, Egide. “Jacques Derrida en de taalfilosofie.” Pages 139-169 in Denken in Parijs. Edited by Egide Berns, Samuel Ijsseling, and Paul Moyaer. Brussel:

Samson, 1979.

Bonner, Gerald. “Augustine as Biblical scholar.” Pages 541-563 in The Cambridge

History of the Bible. Edited by Peter R. Ackroyd and C. F. Evans. Cambridge:

Cambridge University Press, 1989.

Caputo, John. "Mysticism and Transgression: Derrida and Meister Eckhart.” Pages

24-39 in Derrida and Deconstruction. Edited by Hugh J. Silverman. London:

Routledge, 1989.

. The Prayers and Tears of Jacques Derrida. Indianapolis: Indiana University

Press, 1997.

. "Shedding Tears beyond Being." Part II, ch. 5 in Augustine and

Postmodernism: Confessions and Circumfession. Bloomington: Indiana

University Press, 2005. Kindle edition.

Caputo, John D. and Michael J. Scanlon. "Introduction: Apology for the Impossible:

Religion and Postmodern.” Pages 1-19 in God, Gift, and Postmodernism. Edited by John D. Caputo and Michael J. Scanlon. Bloomington: Indiana University Press, 1999.

Derrida, Jacques. Of Grammatology. Baltimore: Johns Hopkins, 1976. . "Circumfession.” Pages 1-316 in Jacques Derrida. Edited by Geoffrey

Bennington and Jacques Derrida. Chicago: University of Chicago, year. . Points ... Stanford: University Press, 1995.

. Limited Inc. Evanston, IL: Northwestern University Press, 1997.

. "Geloof en wete: Die twee bronne van die 'religie' op die grense van die

suiwere rede.” Translated by Johann Rossouw. Fragmente 2 (1998): 14-38. . "Response to Jean-Luc Marion.” Pages 42-53 in God, Gift, and

Postmodernism. Edited by John D. Caputo and Michael J. Scanlon.

Bloomington: Indiana University Press, 1999. Kindle edition. . "Composing 'Circumfession."” Part I, ch. 1in Augustine and

Postmodernism. Confessions and Circumfession. Edited by John D. Caputo and Michael J. Scanlon. Bloomington: Indiana University Press, 2005. Kindle edition.

Drobner, Hubertus R. Lehrbuch der Patrologie. Freiburg: Herder, 1994.

Gadamer, Hans-Georg. Wahrheit und Methode. Tübingen: JCB Mohr, 1990.

Geybels, Hans. “Augustinus een mysticus.” Pages 131-147 in Augustiniana

Neerlandica. Edited by Paul J. van Geest and Johannes van Oort. Leuven:

Peters, 2005.

Glendinning, Simon. Derrida. New York: Oxford University Press, 2011.

Goosen, Daniël. “Verlies, rou en affirmasie: Dekonstruksie en die gebeure.” Frag 1

(1998): 54-79.

Grondin, Jean. Sources of hermeneutics. State University of New York: Albany, 1995.

. Einführung zu Gadamer. Tübingen: JCB Mohr, 2000.

. Einführung in die Philosophische Hermeneutik. Darmstadt:

Wissenschaftliche Buchgesellschaft, 2001.

. "Gadamer's Basic Understanding of Understanding." Pages 36-51 in The

Cambridge Companion to Gadamer. Edited by Robert J. Dostal. Cambridge:

Cambridge University Press, 2002.

Gunkel, Hermann. “The Religio-Historical Interpretation of the New Testament.” 
Monist 13 (1903): 398-455.

Le Roux, Jurie H. “Twee Afrika ma’s en hulle seuns.” Pages 100-120 in Afdrukke. Edited by Dirk J. Human and Daniël P. Veldsman. Pretoria: UP, 2011.

Malabou, Catherine and Jacques Derrida. Counterpath: Travelling with Jacques Derrida. Stanford: Stanford University Press, 2004.

Oger, Erik. Derrida. Kampen: Klement, 2005.

Rutten, Thijs. “Augustinus en de spiritualiteit van de Psalmen.” Pages 113-130 in Augustiniana Neerlandica. Edited by Paul J. van Geest and Johannes van Oort. Leuven: Peters, 2005.

Schmid, Konrad. Is There Theology in the Hebrew Bible? Winona Lake, IN: Eisenbrauns, 2015.

Schoeman, Marinus. “Kritiek en die krisis van representasie.” Fragmente 1 (1998): 95-104.

Van Oort, Johannes. Jeruzalem en Babylon. Zoetermeer: Uitgeverij Boekcentrum, 1995.

Prof. Jurie le Roux, Professor Emeritus, Department of Old Testament Studies, University of Pretoria, Pretoria, South Africa. Email: jleroux1@mweb.co.za. 